\title{
Foraging patterns of gray whales in central Clayoquot Sound, British Columbia, Canada
}

\author{
Jason S. Dunham*, David A. Duffus \\ Whale Research Laboratory, Department of Geography, University of Victoria, PO Box 3050, Victoria, \\ British Columbia V8W 3P5, Canada
}

\begin{abstract}
Gray whales Eschrichtius robustus forage in parts of Clayoquot Sound on several prey species in different habitats. Between June and September in 1996 and 1997 we carried out analyses of the density, biomass, and other measures of their primary prey species, and of whales' movement patterns in response to prey characteristics. The prey base consists of hyper-benthic mysids (family Mysidae), pelagic porcelain crab larvae (4 spp. of family Porcellanidae), benthic amphipods (family Ampeliscidae) and benthic ghost shrimp Callianassa californiensis. Whales foraged primarily for mysids, switching to porcelain crab larvae in August, and then to amphipods even later in the season when these organisms increased in body size. In 1997, whales rapidly switched from feeding on planktonic to benthic prey during mid-August. Sampling indicated low numbers of mysids and crab larvae at that time. Selection of amphipod prey was based on high biomass and a high proportion of individuals $\geq 6 \mathrm{~mm}$ in length. In parts of the study area gray whales did not return to forage on benthic amphipods when this size criteria was not met. A single whale departed from a ghost shrimp feeding ground because its search time for food was long, it achieved only a low biomass removal rate, and it was not able to find sufficient food each day. We show that gray whales are dynamic and selective foragers that switch prey and foraging tactics rapidly to take advantage of short-term availability of energy.
\end{abstract}

KEY WORDS: Gray whale - Eschrichtius robustus · Prey selection · Prey-switching · Plankton · Benthos · Clayoquot Sound

\section{INTRODUCTION}

The primary foraging strategy of baleen whales is to locate dense concentrations of prey, since they cannot obtain their daily caloric requirements by feeding in areas of average food abundance (Nemoto 1970, Brodie 1977, Murison \& Gaskin 1989). The foraging strategy of gray whales Eschrichtius robustus is similar. This species is predominantly a high-Arctic migrant which takes advantage of rich benthic amphipod beds. Numerous observations of gray whales along their migration route between Baja, Mexico and the western Arctic seas report opportunistic foraging along the

*E-mail: jdunham@horizon.bc.ca west coast of North America (Howell \& Huey 1930, Walker 1949, Pike 1962, Pike \& MacAskie 1969, Rice \& Wolman 1971, Hudnall 1983, Norris et al. 1983, Oliver et al. 1983, Murison et al. 1984, Nerini 1984, Sumich 1984, Guerrero 1989, Calambokidis et al. 1991, Weitkamp et al. 1992, Duffus 1996).

Apart from the more recent reports, these studies considered such opportunistic foraging events to be sporadic and transitory. However, as the total population of gray whales reaches estimated historic levels, more whales are at least temporarily abandoning their migratory habit and foraging in habitats along their migration route, taking advantage of whatever prey they encounter that is energetically 'profitable'. When feeding aggregations of whales become large stable associations with many individuals returning to spe- 
cific sites, these groups are equivalent to populations, but not with the same demographic status as biological populations, since they are unlikely to comprise distinct breeding entities. Short-term spatio-temporal grouping may be the most important focus for management. Human activities that affect gray whales, such as whale-watching, hunting by aboriginals and contamination, occur on scales much more applicable to the summer aggregation of whales described in this paper than to the larger Baja to Bering unit typically considered.

The consideration of smaller spatial units in the management of gray whales requires more detailed understanding of their ecology on the same scale. Thus, our objective was to document and analyze at least a part of the 'normal' ecology of gray whales Eschrichtius robustus on the west coast of Vancouver Island, Canada. In this region, aggregations of gray whales spend the boreal summer months feeding on an assemblage of invertebrate prey throughout central Clayoquot Sound. Since gray whales feed on a wide variety of prey items, important aspects of gray whale foraging behavior include prey choice, prey-switching, and the resulting habitat use patterns. While certain aspects of gray whale prey are known, such as abun-

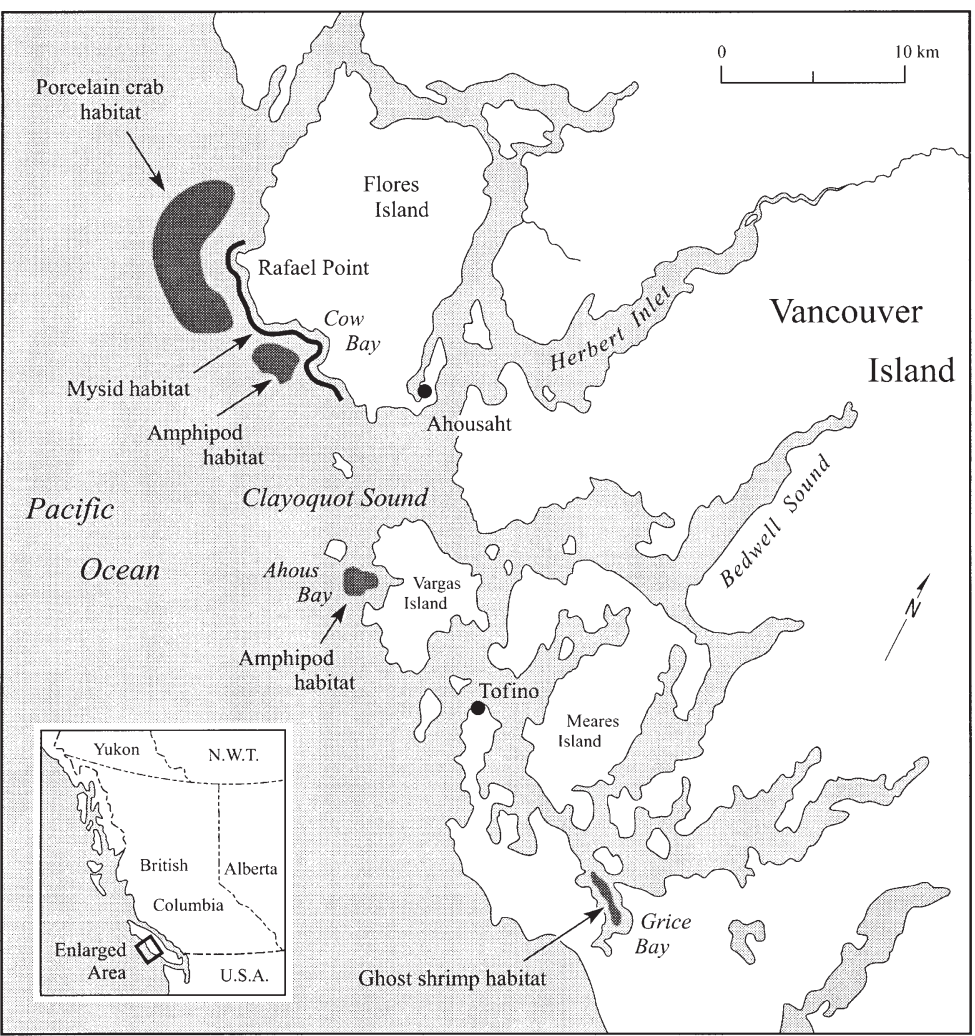

Fig. 1. Habitat of the gray whale Eschrichtius robustus and its prey in central Clayoquot Sound dance (Pike 1962, Moore et al. 1986), patchiness (Clarke et al. 1989) and availability (Gill \& Hall 1983, Moore \& Ljungblad 1984, Clarke et al. 1989), there is little information on prey-switching behavior or habitat use of gray whales feeding in Clayoquot Sound (Duffus 1996).

In this paper, we document those characteristics of their prey that affect whales' prey choices, their subsequent switching between prey items, and their use of prey habitats. We describe whale use of 5 prey habitats located in central Clayoquot Sound. The predominant prey types are hyper-benthic mysids (family Mysidae), pelagic porcelain crab larvae (family Porcellanidae), benthic amphipods (family Ampeliscidae) and benthic ghost shrimp Callianassa californiensis. We employed a quantitative sampling regime to estimate prey density, biomass and size in the various prey habitats. Estimates of these characteristics are linked to observations of whales' foraging patterns in the different prey habitats. By quantifying prey characteristics and whale observations simultaneously, we identified which specific characteristics of the prey caused whales to actively select them.

\section{METHODS}

Study area. We classified 5 gray whale prey habitats in central Clayoquot Sound, British Columbia, based on observations from 1987 to 2000. The study area is a discrete unit bounded on each side by open deeper water and non-productive areas that are rarely, if ever, used by foraging gray whales. Prey habitats are distinguished according to distance from shore, type of substrate, and depth. Free-swimming porcelain crab larvae were collected $>1 \mathrm{~km}$ from shore, over boulder substrate around Rafael Point (Fig. 1), in water depths between 10 and $30 \mathrm{~m}$. Mysids were collected $<1 \mathrm{~km}$ from shore near kelp beds and rock reefs on the south-southwest side of Flores Island, in water 0 to $15 \mathrm{~m}$ deep. Amphipods were collected from the sandy substrate that covers about $10 \mathrm{~km}^{2}$ of the bottom of Cow Bay, in water 0 to $35 \mathrm{~m}$ deep. Amphipods were also collected from the fine-sandy substrate that covers about $8 \mathrm{~km}^{2}$ of the bottom of Ahous Bay, in water 0 to $25 \mathrm{~m}$ deep. Ghost shrimp Callianassa californiensis were collected from littoral sand/mud flats in Grice Bay, in water $<3$ m deep.

Whale distributions. The number of gray whales observed foraging in the study area 
was recorded daily, and individual whales were identified in order to minimize the possibility of individuals being counted twice. In 1996, prey habitats were visited when sampling was conducted, when detailed whale respiration data were recorded, or when we were in transit between sampling sites. In 1997, a transect route was established along the southern and western shorelines of Flores Island. The transect passed through the mysid habitat along the shoreline of Flores Island, the amphipod habitat in Cow Bay, and the porcelain crab larvae habitat near Rafael Point. Vessel speed was constant ( 15 to $20 \mathrm{~km} \mathrm{~h}^{-1}$ ) along the transect route. A minimum of 4 observers covered the $360^{\circ}$ viewing area. In both years, we covered the entire study area daily, weather permitting, with the exception of the amphipod habitat in Ahous Bay and the ghost shrimp habitat in Grice Bay, which were not included in the transect route. We relied on periodic checks in both these bays and information collected by the local research coordinator Rod Palm (Strawberry Isle Research, Tofino) for dates of entry and departure of whales from the bays. Whale observations are standardized by the number of observation days.

Grice Bay is a shallow bay that enabled us to make detailed observations of whale foraging tactics and link them to prey characteristics. Feeding pits $(\mathrm{n}=36)$ in Grice Bay were measured when they were exposed at low tide; only well defined pits with distinct edges were measured. Pit length $(l)$ and width $(w)$ were measured to the nearest $5 \mathrm{~cm}$. Pit area was calculated as the area ( $a$ ) of an ellipse, given by; $a=\pi[0.5(l) \times 0.5(w)]$. Foraging behavior was recorded as follows. The time from emergence of the pectoral fin as the whale rolled onto its side until the fin dropped down again as the whale righted itself was recorded as the time required to excavate a feeding pit. After the whale respired, it normally swam around for a short period of time until it again rolled onto its side to excavate another feeding pit. The time spent swimming after each ventilation until the whale stopped and rolled onto its side was defined as searching behavior.

Gray whales observed foraging in a particular habitat were assumed to be utilizing the prey type characteristic of that habitat. This assumption was based on analyses of whale feces, opportunistic and systematic plankton tows, core samples, SCUBA surveys, and underwater video records collected between 1993 and 2000. Crab larvae carapaces were collected in fecal samples. Both plankton samples taken near foraging whales and visual observation confirmed prey identity. Amphipods were the dominant organisms collected in benthic samples. Small amphipods were also collected in the sediment plumes of whales foraging in the amphipod habitat. Tows in the water column over these sandy bottom bays collected very little plankton.
Clams and ghost shrimp constituted $\geq 98 \%$ of the benthic biomass in Grice Bay, where there is little else upon which whales can forage.

Prey sampling. Prey sampling coordinates were determined using the Canadian Hydrographic Service Field Sheet No. 3603 (1996). Each prey habitat was divided by lines whose intersections created a minimum of 100 possible sampling coordinates. From these coordinates, 6 to 8 sampling sites were randomly chosen before each sampling period. In the field, a GPS was used to navigate the research vessel to each sampling site. During the 2 field seasons, each prey habitat was sampled at consistent time intervals between midJune and early September. In 1996 samples were obtained semi-monthly, resulting in 5 sampling periods during the field season; in 1997 samples were obtained every 4 to $6 \mathrm{wk}$, resulting in 3 sampling periods. We collected samples adjacent to foraging whales in an opportunistic fashion. Foraging whales were defined as whales which remained within a restricted area of a particular habitat and exhibited constant directional changes in movement (Mallonée 1991).

We collected plankton samples with a $2 \times 20 \mathrm{~cm}$ diameter bongo-style plankton net, $80 \mathrm{~cm}$ long, with $500 \mu \mathrm{m}$ mesh size. A mechanical flowmeter (General Oceanics, Miami, FL, Model 2030R) determined the volume of water $\left(\mathrm{m}^{3}\right)$ to calculate standardized density and biomass estimates for the invertebrates. We collected porcelain crab larvae by towing the plankton net from the sea floor to the surface (max. depth = $30 \mathrm{~m}$ ) in oblique tows through the water column. We collected mysids by towing the net horizontally along the bottom. Large samples were subdivided using a Folsom plankton splitter.

We used a $0.06 \mathrm{~m}^{2}$ core sampler (WILDCO Ogeechee Sand Pounder) to collect benthic amphipods in Cow Bay and Ahous Bay. Sediment from each sample was rinsed through a $1 \mathrm{~mm}$ mesh screen to remove amphipods and other invertebrates. Amphipods were categorized into one of 2 size classes: individuals 0 to $5.9 \mathrm{~mm}$ in length were designated 'small' and individuals 6 to $11 \mathrm{~mm}$ 'large'. This classification follows with Rice \& Wolman's (1971) analysis of the stomach contents of gray whales, where prey items measured $>6 \mathrm{~mm}$ in length.

On July 15, 1996, we sampled 5 well-defined excavations created by 1 gray whale foraging in Grice Bay in order to quantify the density and biomass of ghost shrimp inside and outside feeding pits. We collected ghost shrimp with a section of PVC tubing $17 \mathrm{~cm}$ long and $10 \mathrm{~cm}$ in diameter. The tubing was pushed into the sediment and the core and sampler removed with a shovel. We removed 2 samples from inside and outside each feeding depression. Sediment removed from the depressions was rinsed through a $1 \mathrm{~mm}$ mesh screen 
on site, and ghost shrimp were retained. Two samples of sediment were retained to estimate the volume of sediment sampled.

We fixed all invertebrates in formaldehyde and stored them in $70 \%$ ethanol. Small individuals and species that were not known to be potential gray whale prey and that contributed very little to the overall biomass were not identified or counted. Biomass was measured to $0.001 \mathrm{~g}$ blotted wet weight.

We use both parametric and non-parametric tests to analyze our data. Significantly skewed data sets (Kolmogorov-Smirnov test, $\propto=0.05$ ) were analyzed with non-parametric statistical tests.

\section{RESULTS}

Significantly fewer Eschrichtius robustus observations were made in the study area in $1996(\mathrm{n}=171)$ than in $1997(\mathrm{n}=363)\left(\chi^{2}=69.03, \mathrm{df}=1, \mathrm{p}<0.05\right.$; Fig. 2). In 1996, there were $2 \mathrm{~d}$ (August 10 and 11) on which no whales were observed and $19 \mathrm{~d}$ in which only 1 whale was observed (Fig. 2a). In 1997, whales were observed

a)

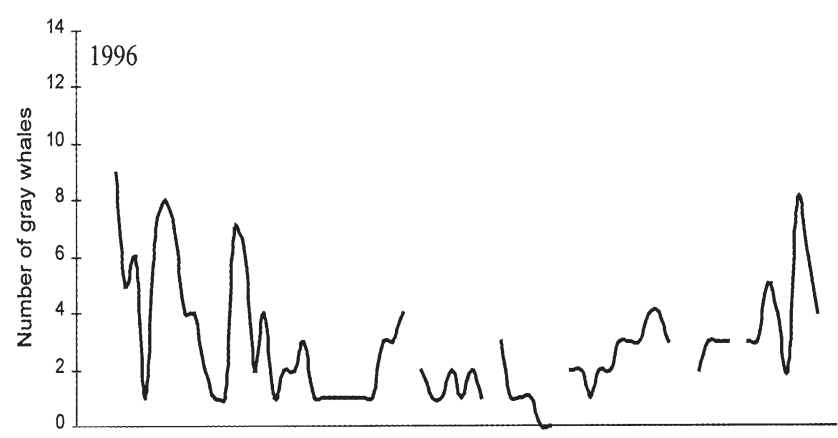

b)

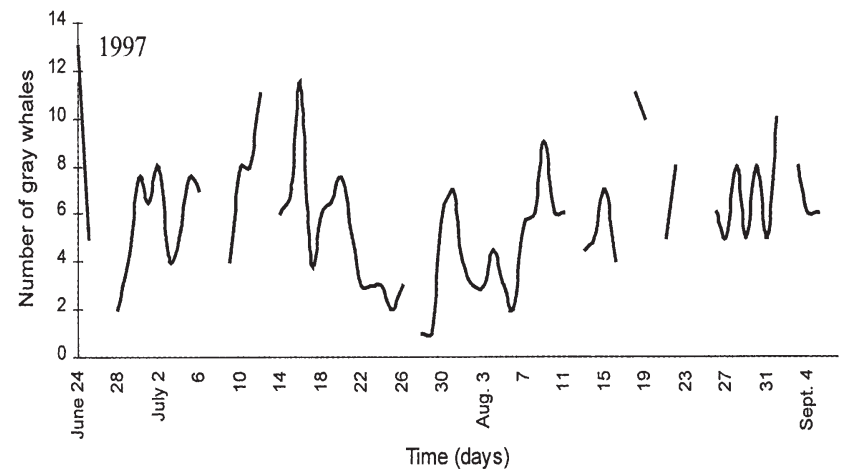

Fig. 2. Eschrichtius robustus. Daily numbers of gray whales observed throughout the study area in central Clayoquot Sound in 1996 and 1997. Breaks in lines are days on which no observations were made due to poor weather conditions each day throughout the field season; on $2 \mathrm{~d}$ (July 28 and 29) only 1 whale was observed (Fig. 2b). Whales foraging on each specific prey type are discussed below.

\section{Mysids}

Mysids were the most consistently eaten prey during the 2 field seasons (Figs. 3a \& 4a). In 1996, whales generally foraged for mysids between Cow Bay and Dagger Point on the northwestern margins of the study area; only on July 4 were 2 whales observed feeding near Fitzpatrick Rocks on the eastern margin of the study area. In contrast, in 1997, whales were consistently observed at Fitzpatrick Rocks between June 15 and July 19. Whales also foraged at Kutcous Point on the extreme eastern end of the study area between July 10 and 18 ; no whales were observed there in 1996. After July 19, whales suddenly abandoned the eastern sectors and moved to forage for mysids near Rafael Point.

The mean number of whales observed feeding in the mysid habitat at any one time was 2.6 in 1996 and 4.3 in

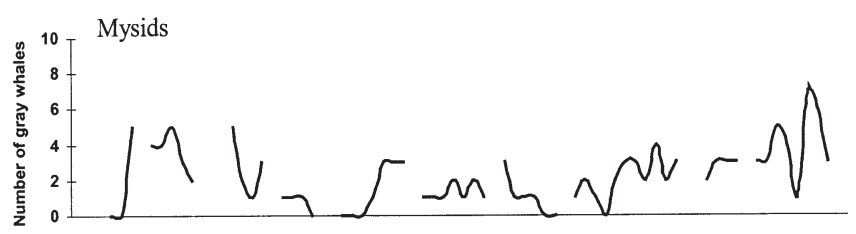

b)

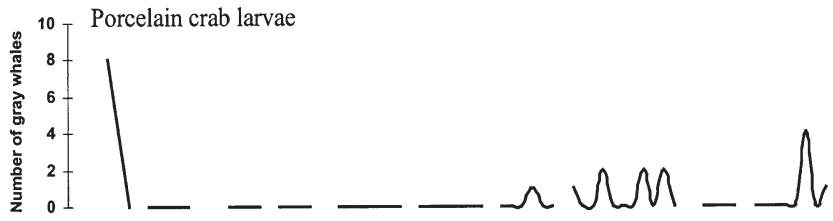

c)

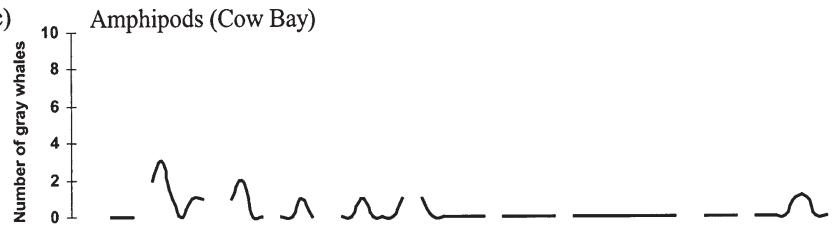

d)

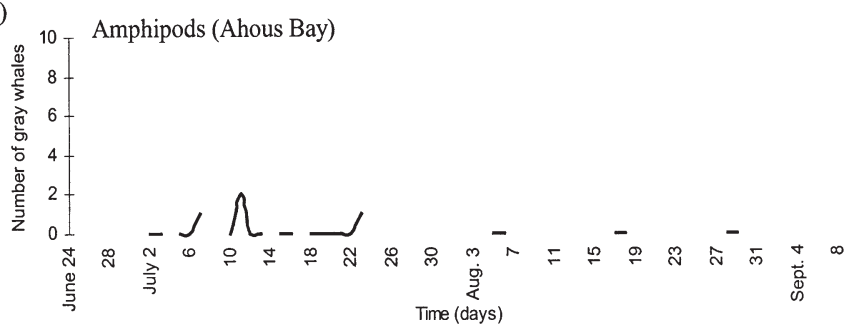

Fig. 3. Eschrichtius robustus. Daily observations of gray whales foraging in each of the 4 prey habitats in central Clayoquot Sound in 1996 
1997 (Table 1). Results of our sampling tows suggest that mysid swarms were not as widely distributed along the shoreline of Flores Island in 1996 as in 1997. Mysid density was significantly lower in 1996 than in 1997 (MannWhitney $U$-test, $Z=-3.32, \mathrm{n}=59, \mathrm{p}=0.00$; Table 2).

When mysids were abundant, whales were present in larger numbers. The largest biomass of mysids $\left(22.6 \mathrm{~g} \mathrm{~m}^{-3}\right)$ collected in the 2 field seasons was obtained on July 4, 1997. A larger number of whale observations ( $\mathrm{n}=151$ ) were recorded around this date (between June 24 and July 23) than during the entire 1996 field season ( $n=131$ ) or after July 23 in 1997 ( $n=109)$. Between June 24 and July 23, 5 to 6 whales (up to 10 individuals in $1 \mathrm{~d}$ ) were observed each day foraging for mysids. The larger numbers of whales observed in the study area in 1997 foraged primarily for mysids (Fig. 4a).

\section{Porcelain crab larvae}

Gray whale presence in the porcelain crab larvae habitat was similar during the 2 field seasons. The proportions of whales foraging for crab larvae were similar in 1996 (17\%) and 1997 (15\%: Table 1) and the total number of whale observations $(n=28)$ made in crab larvae habitat in 1996 was similar to the number ( $\mathrm{n}=$ 26) made in $1997\left(\chi^{2}=0.12\right.$, df $\left.=1, p>0.05\right)$. The mean number of whales observed in the crab larvae habitat during each foraging episode in both years was identical (2.8 whales: Table 1). Crab larvae biomass was similar in 1996 and $1997(Z=-1.52, \mathrm{n}=25, \mathrm{p}=0.13$; Table 2), although density was significantly higher in 1997 ( $Z=-2.16, \mathrm{n}=25, \mathrm{p}=0.03$; Table 2).

In 1996, 7 whale/crab larvae foraging episodes were recorded (Fig. 3b). Eight whales were observed foraging for crab larvae on June 28, falling to 4 individuals on June 29. On June 29 we obtained the highest density $\left(10520 \mathrm{~m}^{3}\right)$ and biomass $\left(16.7 \mathrm{~g} \mathrm{~m}^{-3}\right)$ of crab larvae collected in 1996. No whales were observed foraging for crab larvae between June 30 and August 8. During this period, crab biomass estimates ranged from 0 to $0.59 \mathrm{~g} \mathrm{~m}^{-3}$.

In 1997, 6 whale/crab larvae foraging episodes were recorded (Fig. 4b). The maximum number of whales that foraged in the crab larvae habitat was 6 whales on August 18. On this date, the highest density $\left(13198 \mathrm{~m}^{3}\right)$ and biomass $\left(20.6 \mathrm{~g} \mathrm{~m}^{-3}\right)$ of crab larvae were obtained. No whales were observed foraging for crab larvae between June 24 and July 23 and after August 25. During these periods porcelain crab larvae biomass estimates ranged from 0 to $0.07 \mathrm{~g} \mathrm{~m}^{-3}$. a)

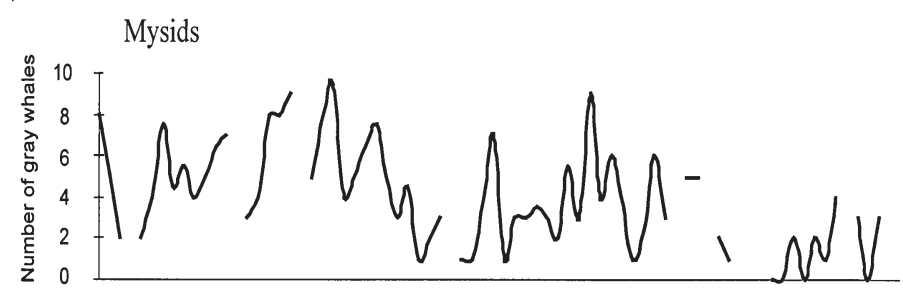

b)

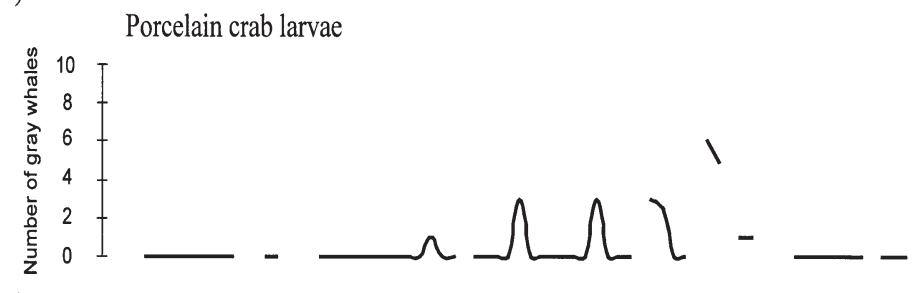

c)

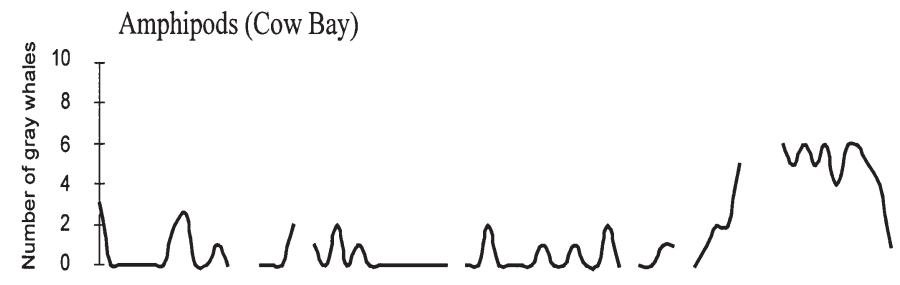

d)

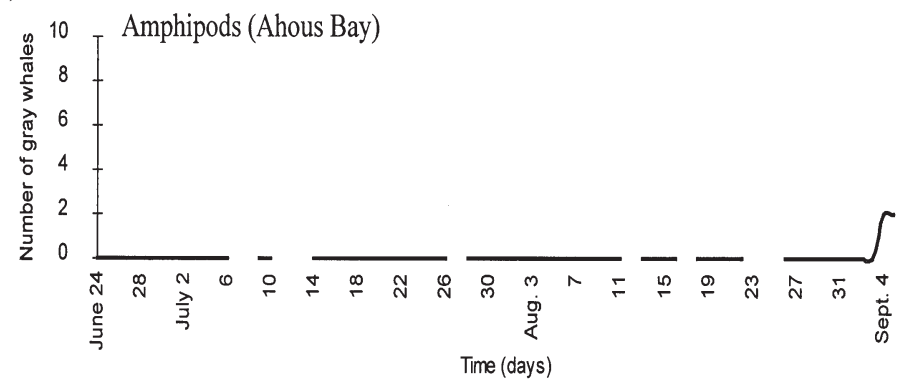

Fig. 4. Eschrichtius robustus. Daily observations of gray whales foraging in each of the 4 prey habitats in central Clayoquot Sound in 1997
Table 1. Eschrichtius robustus. Observations of gray whales foraging in each prey habitat in central Clayoquot Sound in 1996 and 1997. \% of days: \% of days whale(s) observed foraging in each prey habitat; no. observed: mean $( \pm \mathrm{SD})$ no. of whale(s) observed foraging simultaneously

\begin{tabular}{|lcccc|}
\hline \multirow{2}{*}{ Prey } & \multicolumn{2}{c}{$\begin{array}{c}\text { 1996 (Jun 28-Sep 9) } \\
\text { \% of days }\end{array}$} & $\begin{array}{c}\text { No. observed } \\
\text { \% of days (Jun 24-Sep 7) }\end{array}$ & No. observed \\
\hline Mysids & 85 & $2.6 \pm 1.5$ & 94 & $4.3 \pm 2.3$ \\
Porcelain crab larvae & 17 & $2.8 \pm 2.1$ & 15 & $2.8 \pm 1.8$ \\
Amphipods in Cow Bay & 18 & $1.4 \pm 0.7$ & 47 & $2.9 \pm 1.9$ \\
Amphipods in Ahous Bay & 13 & $1.3 \pm 0.6$ & 3 & $2.0 \pm 0.0$ \\
Ghost shrimp & 34 & $1.0 \pm 0.0$ & 0 & $0.0 \pm 0.0$ \\
\hline
\end{tabular}


Table 2. Planktonic prey density and biomass near feeding Eschrichtius robustus. Data are means \pm SD, and median inter quartile range [IQR] for 1996 and 1997

\begin{tabular}{|lcccc|}
\hline Prey & \multicolumn{2}{c}{1996} & \multicolumn{2}{c|}{1997} \\
& $\begin{array}{c}\text { Density } \\
\left(\mathrm{m}^{3}\right)\end{array}$ & $\begin{array}{c}\text { Biomass } \\
\left(\mathrm{g} \mathrm{m}^{-3}\right)\end{array}$ & $\begin{array}{c}\text { Density } \\
\left(\mathrm{m}^{3}\right)\end{array}$ & $\begin{array}{c}\text { Biomass } \\
\left(\mathrm{g} \mathrm{m}^{-3}\right)\end{array}$ \\
\hline Mysids & $\begin{array}{c}10[53] \\
(\mathrm{n}=25)\end{array}$ & $\begin{array}{c}0.32[1.56] \\
(\mathrm{n}=12)\end{array}$ & $\begin{array}{c}175[746] \\
(\mathrm{n}=34)\end{array}$ & $\begin{array}{c}1.43[6.00] \\
(\mathrm{n}=36)\end{array}$ \\
$\begin{array}{l}\text { Porcelain crab } \\
\text { larvae }\end{array}$ & $\begin{array}{c}3006 \pm 3718 \\
(\mathrm{n}=17)\end{array}$ & $\begin{array}{c}4.61 \pm 6.09 \\
(\mathrm{n}=17)\end{array}$ & $\begin{array}{c}4726 \pm 4598 \\
(\mathrm{n}=8)\end{array}$ & $\begin{array}{c}6.16 \pm 7.54 \\
(\mathrm{n}=8)\end{array}$ \\
\hline
\end{tabular}

that when crab larvae were concentrated in patches a comparable amount of food was available for whales from the 2 prey types.

Only on June 28, 1996 did all 8 gray whales in the study area forage exclusively on crab larvae. The largest biomass estimate we collected during the 2 yr study was obtained on June 29, so there may have been an unusually large food source available during those $2 \mathrm{~d}$.

In general, whales foraged sporadically and for short periods of time on crab larvae. Observations of feeding whales indicated that crab larvae swarm in densities sufficient to attract whales for 2 to $3 \mathrm{~d}$ at a time. Gray whales generally foraged for crab larvae during August in both years (Figs 3b \& 4b).

Proportions of the Zoea I and II larval stages determined for each sampling date in both years indicated that reproductive events for porcelain crabs occurred in August, at least in 1997. There was a large increase in the number of crab larvae in the Zoea I larval stage at the end of July, and a concomitant increase in the number of individuals in the Zoea II larval stage during the last 2 wk of August (Fig. 5). Reproductive events of Pachycheles spp. and Petrolisthes spp. at the beginning of August may have provided sufficient biomass to have attracted foraging gray whales throughout the month.

At particular times, gray whales were observed foraging in mysid and crab larvae habitats concurrently. In every case but one, not all whales left the mysid habitat to feed in the crab larvae habitat when crab larvae were sufficiently concentrated: whales normally spread out among the 2 food sources to forage. Mysid biomass ( $\mathrm{n}=$ 36) in 1997 was similar to porcelain crab larvae biomass (n = 25) in 1996 and 1997 near foraging whales $(Z=$ $-1.25, \mathrm{p}=0.21$; Table 2). In addition, maximum biomass estimates for mysids and crab larvae in both years were similar (22.6 and $20.6 \mathrm{~g} \mathrm{~m}^{-3}$ respectively). This suggests

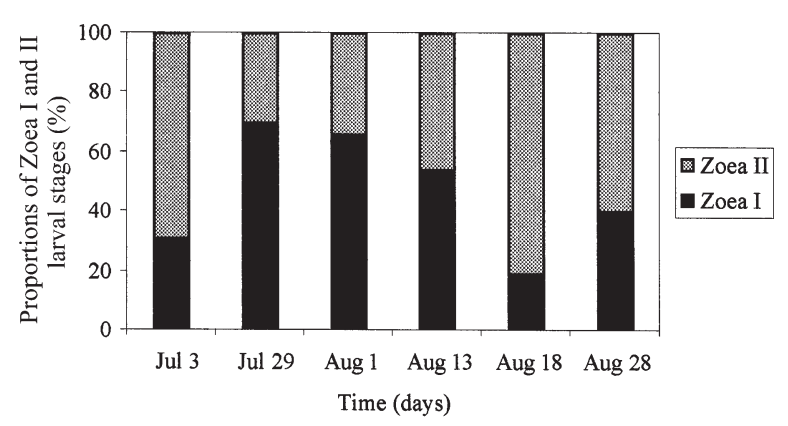

Fig. 5. Seasonal occurrence of Zoea I and II stage porcelain crab larvae, in central Clayoquot Sound, in 1997
Although quantitative sampling of the 2 types of planktonic prey indicate that there were comparable amounts of prey available to the whales, observations of the number and locations of feeding whales suggest that mysids were generally a more prevalent and consistent prey source than porcelain crab larvae (Table 1, Figs $3 \& 4 a, b)$.

\section{Benthic amphipods}

Between June 28 and September 9, 1996, we only occasionally observed gray whales foraging on the bottom in Cow Bay and Ahous Bay (Fig. 3c,d). In Cow Bay, no whales were observed foraging benthically between July 30 and September 3 (Fig. 3c). Whales that were observed in the bay did not remain for long periods of time; only on 2 occasions (July 2 and 3 and September 4 and 5) were whales observed foraging benthically for 2 consecutive days. In Ahous Bay, 1 or 2 whales were observed on July 7,11 and 23, but these whales did not remain for more than $1 \mathrm{~d}$ in the bay (Fig. 3d).

In 1996, amphipod populations in Cow Bay and Ahous Bay were similar in terms of density $(Z=-0.79$,

Table 3. Characteristics of amphipods at sites where no Eschrichtius robustus were observed in 1996. Data are means $\pm \mathrm{SD}$

\begin{tabular}{|lcc|}
\hline Characteristics & $\begin{array}{c}\text { Cow Bay } \\
(\mathrm{n}=47)\end{array}$ & $\begin{array}{c}\text { Ahous Bay } \\
(\mathrm{n}=54)\end{array}$ \\
\hline Density $\left(\mathrm{m}^{2}\right)$ & $16121 \pm 20187$ & $10654 \pm 11741$ \\
Biomass $\left(\mathrm{g} \mathrm{m}^{-2}\right)$ & $48 \pm 54$ & $36 \pm 46$ \\
Length & & \\
$0-5.9 \mathrm{~mm}$ & $3.4 \pm 0.7$ & $3.5 \pm 0.8$ \\
& $(\mathrm{n}=1257)$ & $(\mathrm{n}=870)$ \\
$6-11 \mathrm{~mm}$ & $7.9 \pm 1.2$ & $7.7 \pm 1.2$ \\
& $(\mathrm{n}=83)$ & $(\mathrm{n}=119)$ \\
Proportion & & \\
$0-5.9 \mathrm{~mm}$ & 94 & 88 \\
$6-11 \mathrm{~mm}$ & 6 & 12 \\
\hline
\end{tabular}


$\mathrm{n}=68, \mathrm{p}=0.43)$ and biomass $(Z=-1.04$, $\mathrm{n}=67, \mathrm{p}=0.30$; Table 3 ). 'Small' (0 to $5.9 \mathrm{~mm})$ amphipods had similar mean lengths in both bays $(Z=-1.63, \mathrm{n}=$ 2127, $\mathrm{p}=0.10$ ), as did 'large' (6 to 11 $\mathrm{mm}$ ) amphipods (Student's $t$-test, $t=$ 1.17, df $=180, p=0.24)$. Both bays had a high proportion of small amphipods and a corresponding low proportion of large amphipods (Table 3).

Consistent bottom-foraging behavior by gray whales was only observed in Cow Bay in 1997. From June 24 to August 21 (49 observation days), between 1 and 3 whales were observed on 17 different days (approximately 1 in every $4 \mathrm{~d}$ ) bottom-feeding in Cow Bay (Fig. 4c). However, on August 22 and 23, there was a rapid increase in the number of whales foraging on benthic prey in the bay. Between August 22 and September 4, 4 to 6 whales foraged continuously in Cow Bay on amphipods (Fig. 4c, Table 4). The maximum number of whales observed simultaneously feeding on benthic prey was 6 .

Amphipod density $\left(26260 \pm 23716 \mathrm{~m}^{-2}\right)$ and biomass $\left(73 \pm 51 \mathrm{~g} \mathrm{~m}^{-2}\right)$ estimates $(\mathrm{n}=34)$ obtained in 1996 from water depths ranging between 16 and $25 \mathrm{~m}$ were compared to density $\left(11054 \pm 4151 \mathrm{~m}^{-2}\right)$ and biomass $(113 \pm$ $28 \mathrm{~g} \mathrm{~m}^{-2}$ ) estimates $(\mathrm{n}=21$ ) obtained in 1997 from similar depths (between 18 and $24 \mathrm{~m}$ ) near feeding whales. Although amphipod density was significantly higher in $1996(Z=-2.91, \mathrm{n}=55, \mathrm{p}=0.00)$, biomass was higher in 1997 ( $t=-3.28$, df $=53, \mathrm{p}=0.00)$.

Amphipod size changed as summer progressed. In 1996 in Cow Bay, amphipod density (ANOVA, $F=$ 1.75 , df $=31, \mathrm{p}=0.17)$, as well as biomass $(F=1.05$, $\mathrm{df}=31, \mathrm{p}=0.40$ ), was similar between June 29 and
September 2 (Table 5). 'Small' amphipods increased in length by $1 \mathrm{~mm}$ as the summer progressed (Kruskal-Wallis, $\chi^{2}=400.63, \mathrm{n}=1257$, $\mathrm{df}=4, \mathrm{p}=0.00$; Table 5), but 'large' amphipods were not significantly larger over time $(F=1.47, \mathrm{df}=73, \mathrm{p}=0.22$; Table 5). During the 2 field seasons in Cow Bay, amphipod density and biomass did not change between late June/early July and late August/early September. However, amphipod size did increase as summer progressed in both years: 'small' amphipods increased in size in 1996, whereas 'large' amphipods increased in size in 1997.

Amphipods also displayed size changes over time in Ahous Bay. In 1996, amphipod density was similar $(F=$ $0.63, \mathrm{df}=35, \mathrm{p}=0.65)$, as well as biomass $(F=0.52, \mathrm{df}=$ $34, \mathrm{p}=0.72$ ), between July 2 and August 29 (Table 6). 'Small' amphipods increased in length by $1 \mathrm{~mm}$ as the summer progressed $\left(\chi^{2}=219.70, \mathrm{n}=870, \mathrm{df}=4, \mathrm{p}=\right.$ 0.00). In contrast, 'large' amphipods were not significantly larger $(F=0.41$, df $=107, \mathrm{p}=0.80)$. In 1997, amphipod density $(t=2.02, \mathrm{df}=8.58, \mathrm{p}=0.08)$ and bio-

Table 5. Characteristics of amphipods in Cow Bay in 1996 and 1997. Data are means \pm SD and median inter quartile range [IQR]. Percent: percentage of amphipods in that size class

\begin{tabular}{|c|c|c|c|c|c|c|c|c|}
\hline \multirow{2}{*}{ Characteristics } & \multirow{2}{*}{$\begin{array}{l}\text { Jun } 29 \\
(\mathrm{n}=7)\end{array}$} & \multirow[b]{2}{*}{$\begin{array}{c}\text { Jul 21, } 22 \\
(\mathrm{n}=10)\end{array}$} & \multirow{2}{*}{$\begin{array}{c}-1996- \\
\text { Aug 3, } \\
(\mathrm{n}=10)\end{array}$} & \multirow[b]{2}{*}{$\begin{array}{l}\text { Aug 16 } \\
(\mathrm{n}=10)\end{array}$} & \multirow[b]{2}{*}{$\begin{array}{c}\text { Aug 31, Sep } 2 \\
(\mathrm{n}=10)\end{array}$} & \multirow[b]{2}{*}{$\begin{array}{c}\text { Jul } 2 \\
(\mathrm{n}=19)\end{array}$} & \multirow{2}{*}{$\begin{array}{c}-1997 \\
\text { Jul } 16,31 \\
(\mathrm{n}=7)\end{array}$} & \multirow[b]{2}{*}{$\begin{array}{c}\text { Aug 20, } 21 \\
(\mathrm{n}=10)\end{array}$} \\
\hline & & & & & & & & \\
\hline Density $\left(\mathrm{m}^{2}\right)$ & $38258 \pm 39747$ & $8996 \pm 8580$ & $\begin{array}{c}5764 \\
{[23200]}\end{array}$ & $10889 \pm 9331$ & $\begin{array}{cc}1 & 16139 \\
{[32278]}\end{array}$ & $10951 \pm 5241$ & $11445 \pm 3076$ & $10721 \pm 6065$ \\
\hline Biomass $\left(\mathrm{g} \mathrm{m}^{-2}\right)$ & ) $55 \pm 51$ & $29 \pm 25$ & $17[78]$ & $33 \pm 29$ & 59 [124] & $90 \pm 36$ & $123 \pm 21$ & $132 \pm 84$ \\
\hline \multicolumn{9}{|l|}{ Length } \\
\hline $0-5.9 \mathrm{~mm}$ & $\begin{array}{l}3.0 \pm 0.6 \\
(\mathrm{n}=428)\end{array}$ & $\begin{array}{l}3.4 \pm 0.7 \\
(\mathrm{n}=154)\end{array}$ & $\begin{array}{l}3.3 \pm 0.6 \\
(n=231)\end{array}$ & $\begin{array}{l}3.9 \pm 0.6 \\
(\mathrm{n}=152)\end{array}$ & $\begin{array}{l}3.9 \pm 0.6 \\
(n=292)\end{array}$ & $\begin{array}{l}4.2 \pm 1.3 \\
(\mathrm{n}=159)\end{array}$ & $\begin{array}{c}4.5 \pm 1.3 \\
(\mathrm{n}=52)\end{array}$ & $\begin{array}{c}3.9 \pm 0.8 \\
(\mathrm{n}=38)\end{array}$ \\
\hline $6-11 \mathrm{~mm}$ & $\begin{array}{c}8.2 \pm 1.5 \\
(\mathrm{n}=6)\end{array}$ & $\begin{array}{l}7.3 \pm 0.9 \\
(\mathrm{n}=21)\end{array}$ & $\begin{array}{c}7.9 \pm 1.1 \\
(\mathrm{n}=28)\end{array}$ & $\begin{array}{c}7.8 \pm 1.5 \\
(\mathrm{n}=6)\end{array}$ & $\begin{array}{l}8.2 \pm 1.3 \\
(\mathrm{n}=220)\end{array}$ & $\begin{array}{l}7.0 \pm 1.0 \\
(\mathrm{n}=180)\end{array}$ & $\begin{array}{c}7.1 \pm 0.9 \\
(\mathrm{n}=89)\end{array}$ & $\begin{array}{l}7.9 \pm 1.1 \\
(\mathrm{n}=139)\end{array}$ \\
\hline \multicolumn{9}{|l|}{ Percent } \\
\hline $0-5.9 \mathrm{~mm}$ & 99 & 88 & 89 & 96 & 93 & 47 & 37 & 21 \\
\hline $6-11 \mathrm{~mm}$ & 1 & 12 & 11 & 4 & 7 & 53 & 63 & 79 \\
\hline
\end{tabular}


Table 6. Characteristics of amphipods in Ahous Bay in 1996 and 1997. Data are means \pm SD and median inter quartile range [IQR]. Percent: percentage of amphipods in that size class

\begin{tabular}{|c|c|c|c|c|c|c|c|}
\hline \multirow[t]{2}{*}{ Characteristics } & \multirow[b]{2}{*}{$\begin{array}{l}\text { Jul 2, } 3 \\
(\mathrm{n}=10)\end{array}$} & \multirow[b]{2}{*}{$\begin{array}{c}\text { Jul 19, 20, } 22 \\
(\mathrm{n}=10)\end{array}$} & \multirow{2}{*}{$\begin{array}{c}1996 \\
\text { Aug } 6 \\
(\mathrm{n}=11)\end{array}$} & \multirow[b]{2}{*}{$\begin{array}{l}\text { Aug } 18 \\
(\mathrm{n}=12)\end{array}$} & \multirow[b]{2}{*}{$\begin{array}{l}\text { Aug } 29 \\
(\mathrm{n}=11)\end{array}$} & \multirow{2}{*}{$\begin{array}{l}\text { Jul 9,10 } \\
(\mathrm{n}=19)\end{array}$} & \multirow{2}{*}{$7 \begin{array}{c}\text { Sep } 2 \\
(\mathrm{n}=10)\end{array}$} \\
\hline & & & & & & & \\
\hline Density $\left(\mathrm{m}^{2}\right)$ & $12784 \pm 10358$ & $\begin{array}{c}8069 \\
{[19021]}\end{array}$ & $\begin{array}{c}6917 \\
{[12335]}\end{array}$ & $5187 \pm 4981$ & $\begin{array}{c}6917 \\
{[24821]}\end{array}$ & $16880 \pm 11087$ & $7493 \pm 5272$ \\
\hline Biomass $\left(\mathrm{g} \mathrm{m}^{-2}\right)$ & $22 \pm 16$ & $39 \pm 41$ & $30 \pm 24$ & $34 \pm 36$ & 12 [102] & $89 \pm 54$ & $58 \pm 55$ \\
\hline \multicolumn{8}{|l|}{ Length } \\
\hline $0-5.9 \mathrm{~mm}$ & $\begin{array}{l}3.0 \pm 0.6 \\
(n=203)\end{array}$ & $\begin{array}{l}3.5 \pm 0.8 \\
(\mathrm{n}=141)\end{array}$ & $\begin{array}{l}3.4 \pm 0.6 \\
(\mathrm{n}=175)\end{array}$ & $\begin{array}{l}4.0 \pm 0.8 \\
(n=103)\end{array}$ & $\begin{array}{l}3.7 \pm 0.8 \\
(n=248)\end{array}$ & $\begin{array}{l}3.2 \pm 1.0 \\
(\mathrm{n}=498)\end{array}$ & $\begin{array}{l}3.6 \pm 1.0 \\
(n=63)\end{array}$ \\
\hline $6-11 \mathrm{~mm}$ & $\begin{array}{c}7.4 \pm 1.5 \\
(\mathrm{n}=8)\end{array}$ & $\begin{array}{l}7.8 \pm 1.5 \\
(\mathrm{n}=15)\end{array}$ & $\begin{array}{l}7.6 \pm 0.9 \\
(\mathrm{n}=22)\end{array}$ & $\begin{array}{l}7.8 \pm 1.1 \\
(\mathrm{n}=41)\end{array}$ & $\begin{array}{l}7.5 \pm 1.2 \\
(\mathrm{n}=33)\end{array}$ & $\begin{array}{l}6.8 \pm 0.7 \\
(n=154)\end{array}$ & $\begin{array}{l}7.0 \pm 0.9 \\
(\mathrm{n}=75)\end{array}$ \\
\hline \multicolumn{8}{|l|}{ Percent } \\
\hline $0-5.9 \mathrm{~mm}$ & 96 & 90 & 89 & 72 & 88 & 76 & 46 \\
\hline $6-11 \mathrm{~mm}$ & 4 & 10 & 11 & 28 & 12 & 24 & 54 \\
\hline
\end{tabular}

mass $(t=1.07, \mathrm{df}=12, \mathrm{p}=0.31)$ remained similar between July and September (Table 6). 'Small' amphipods were larger by $0.4 \mathrm{~mm}$ in September $(Z=$ $-4.56, \mathrm{n}=561, \mathrm{p}=0.00)$. In contrast, 'large' amphipods were not significantly bigger between the 2 sampling periods $(Z=-0.42, \mathrm{n}=218, \mathrm{p}=0.68$; Table 6$)$. Therefore, during the 2 field seasons in Ahous Bay, amphipod density and biomass did not change significantly between early July and September. However, 'small' amphipods were larger later in the summer of both years.

Amphipod size may be important in determining gray whales' choices of benthic foraging grounds. Amphipod density $(F=0.20$, df $=37, \mathrm{p}=0.82)$ and biomass $(F=1.78, \mathrm{df}=37, \mathrm{p}=0.18)$ at sites where whales were present in Cow Bay were similar to those at sites where whales were absent in Cow Bay

Table 7. Characteristics of amphipods at sites where Eschrichtius robustus foraged or did not forage in 1997. Data are means \pm SD. Percent: percentage of amphipods in that size class

\begin{tabular}{|lccc|}
\hline Characteristics & $\begin{array}{c}\text { Foraging whales present } \\
\text { Cow Bay } \\
(\mathrm{n}=21)\end{array}$ & $\begin{array}{c}\text { No whales present } \\
\text { Cow Bay } \\
(\mathrm{n}=19)\end{array}$ & $\begin{array}{c}\text { Ahous Bay } \\
(\mathrm{n}=29)\end{array}$ \\
\hline Density $\left(\mathrm{m}^{2}\right)$ & $11054 \pm 4151$ & $10332 \pm 6704$ & $12186 \pm 9659$ \\
Biomass $\left(\mathrm{g} \mathrm{m}^{-2}\right)$ & $113 \pm 28$ & $97 \pm 80$ & $74 \pm 55$ \\
Length & & & \\
$0-5.9 \mathrm{~mm}$ & $4.3 \pm 1.3$ & $4.1 \pm 1.2$ & $3.3 \pm 1.0$ \\
& $(\mathrm{n}=157)$ & $(\mathrm{n}=155)$ & $(\mathrm{n}=561)$ \\
$6-11 \mathrm{~mm}$ & $7.1 \pm 1.0$ & $7.5 \pm 1.2$ & $6.9 \pm 0.8$ \\
$(\mathrm{n}=246)$ & $(\mathrm{n}=207)$ & \\
Percent & & & 73 \\
$0-5.9 \mathrm{~mm}$ & 39 & 57 & $229)$ \\
$6-11 \mathrm{~mm}$ & 61 & & \\
\hline
\end{tabular}

and Ahous Bay (Table 7). However, amphipod sizes were significantly different between areas in which whales did and did not forage. 'Small' amphipods were significantly larger in Cow Bay, especially where whales foraged, than in Ahous Bay $\left(\chi^{2}=\right.$ 105.74, $\mathrm{n}=879$, df $=2, \mathrm{p}=0.00$ ), and also 'large' amphipods were significantly larger in Cow Bay than in Ahous Bay, particularly in areas of Cow Bay where no whales were initially observed $\left(\chi^{2}=25.68, \mathrm{n}=671\right.$, $\mathrm{df}=2, \mathrm{p}=0.00)$. Where gray whales foraged in Cow Bay, there was a higher proportion (61\%) of large amphipods compared to similar-sized amphipods in Ahous Bay (29\%; Table 7).

No gray whales were observed bottom feeding in Ahous Bay until September 4 (Fig. 4d). Two whales remained in the bay for at least $2 \mathrm{~d}$, but we do not know whether they remained there for a longer period of time. Amphipods were, on average, smaller in Ahous Bay than in Cow Bay in July $(Z=-8.99, \mathrm{n}$ $=874, \mathrm{p}=0.00$ ) and near the end of August/beginning of September $(Z=-7.06$, $\mathrm{n}=266, \mathrm{p}=0.00)$. Not until September did amphipods in Ahous Bay attain the sizes that amphipods in Cow Bay had reached in July $(Z=-1.01, \mathrm{n}=367, \mathrm{p}=$ 0.31; Table 8).

\section{Ghost shrimp}

In 1996, a single gray whale foraged in Grice Bay. Seven days before this whale departed from the bay, significantly more ghost shrimp were collected outside (1170 shrimp) than inside (405 shrimp) feeding pits (paired $t$-test, $t=-3.64$, df $=9, \mathrm{p}=0.01$ ), indicating a 
$65 \%$ removal rate by numbers. Ghost shrimp biomass was $30 \mathrm{~g} \mathrm{~m}^{-2}$ outside and $19 \mathrm{~g} \mathrm{~m}^{-2}$ inside feeding pits, indicating a $37 \%$ removal rate of biomass. This removal rate estimate, however, is not significant (paired $t$-test, $t=-0.98$, $\mathrm{df}=9, \mathrm{p}=0.35$ ). The mean dimension of feeding pits made by the whale was $2.9 \pm 0.4 \mathrm{~m}$ long (mean $\pm \mathrm{SD}$ ), $2.0 \pm$ $0.3 \mathrm{~m}$ wide, encompassing an area of $4.6 \pm 1.0 \mathrm{~m}^{2}(\mathrm{n}=36)$. An average of $54 \mathrm{~g}$ of shrimp were removed per pit. Ghost shrimp sizes inside (18 \pm $18 \mathrm{~mm})$ and outside $(17 \pm 17 \mathrm{~mm})$ the feeding pits were not significantly different (Student's $t$-test, $t=0.81$, $\mathrm{df}=62, \mathrm{p}=0.42$ ).

Grice Bay mud flats were only accessible to the whale during high tide. Generally, the tide level was high enough for the whale to forage approximately $12 \mathrm{~h}$ each day. It is unknown whether it foraged at night, but we assume that the whale could forage for $12 \mathrm{~h}$ each day. A whale requires between 400 (Nerini 1984) and $1200 \mathrm{~kg}$ (Zimushko \& Lenskaya 1970) of prey each day. If $54 \mathrm{~g}$ of ghost shrimp biomass were removed from each feeding pit, then the whale would have had to create 7407 to 22222 pits in $12 \mathrm{~h}$ to attain the consumption 'estimates above', assuming that ghost shrimp are not an exceptionally high-yield prey. This means that the whale would have had to excavate a new feeding pit every 2 to $6 \mathrm{~s}$.

The clam Cryptomya californica was so prevalent throughout Grice Bay that we thought this organism, in addition to ghost shrimp, might provide an important source of energy to the whale. If clam biomass was included in the whale's intake, then $302 \mathrm{~g}$ of clam biomass removed from each feeding pit would be added to the $54 \mathrm{~g}$ of ghost shrimp biomass, making a total ghost shrimp and clam biomass removal from each feeding pit of $356 \mathrm{~g}$. In this scenario, the whale would have had to excavate between 1124 and 3371 pits in $12 \mathrm{~h}$, meaning that a new feeding pit would have had to be created every 13 to $38 \mathrm{~s}$ to achieve the above consumption estimates.

To compare expected pit-making times, we made detailed observations of the whale on July 1, $21 \mathrm{~d}$ before its departure from the bay. The time required for the whale to excavate a feeding pit was $25 \pm 11 \mathrm{~s}$ $(n=11)$. In general, $54 \%$ of the entire time period in which the whale was observed involved searching behavior, while $46 \%$ was spent feeding and breathing. This suggests that $34 \%$ of the whale's foraging time or $4.1 \mathrm{~h}$ per day was spent actively making feeding pits. Thus, the whale had time to excavate 598 feeding pits in $12 \mathrm{~h}$, which equals one pit every $72 \mathrm{~s}$.

\section{Benthic-pelagic prey-switching}

Before August 22 in 1997, we observed gray whales foraging in planktonic prey habitats, primarily for mysids (Fig. 4a; Table 4). After August 22, the number of whales observed feeding in pelagic prey habitats decreased and the number of whales observed feeding in the benthic prey habitat in Cow Bay increased. More whales had not simply entered the study area to feed benthically; rather whales which had previously been feeding on planktonic prey switched to benthic prey (Table 4).

Reasons for gray whales switching from planktonic to benthic prey are either substantial increases in amphipod populations and biomass, or decreases in planktonic organism populations and biomass. Our data indicate there were no substantial changes in amphipod populations in Cow Bay as the summer progressed. Amphipod density $(F=0.04, \mathrm{df}=35, \mathrm{p}=0.96)$ and biomass $(F=2.48$, df $=35, \mathrm{p}=0.10)$ were similar between July 2 and August 21 (Table 5). 'Small' amphipods did not increase in length as the summer progressed $\left(\chi^{2}=3.98, \mathrm{n}=249, \mathrm{df}=2, \mathrm{p}=0.14\right)$. Only 'large' amphipods were significantly bigger (by $0.9 \mathrm{~mm}$ ) in August $\left(\chi^{2}=66.54, \mathrm{n}=408, \mathrm{df}=2, \mathrm{p}=0.00\right)$. Also, a higher proportion of 'large' amphipods was collected in August than in July (Table 5). Amphipod size, therefore, was the only variable that changed significantly as the summer progressed.

We believe decreased abundance of planktonic prey items played a bigger part than subtle changes in amphipod size to induce gray whales to feed on amphipods in 1997. No mysids were found in 12 plankton samples collected between August 19 and 31 at sites near Fitzpatrick Rocks where mysids had previously been sufficiently abundant to attract foraging whales. Whales had already abandoned this area when these samples were collected; however, several individuals were observed foraging in the mysid habitat about $10 \mathrm{~km}$ away at Rafael Point. The smallest number of whale observations $(n=18)$ was recorded in the mysid habitat between August 22 and September 7. In addition, crab larvae biomass was low (0.01 to $0.07 \mathrm{~g} \mathrm{~m}^{-3}$ ) in samples taken on August 28. No whales were observed foraging in the porcelain crab larvae habitat after August 25 (Fig. 4b). 
In contrast, during August and September in 1996, gray whales were observed foraging in planktonic rather than in amphipod prey habitats. Whales may have avoided amphipod habitats because mysids and, to a lesser extent, porcelain crab larvae were abundant during August and September. The maximum density of mysids $\left(326 \mathrm{~m}^{-3}\right)$ collected during the 1996 field season was on September 1. Density of crab larvae collected on September 5 near 4 feeding whales was estimated to be $2776 \pm 1761 \mathrm{~m}^{-3}$.

\section{DISCUSSION AND CONCLUSIONS}

Mysids were the prey most extensively foraged by gray whales Eschrichtius robustus in central Clayoquot Sound between June and September. Although specific locations where mysids were collected changed, these invertebrates were always available at some sites along the shoreline of Flores Island. Since kelp forests fringe much of the gray whales' migration route south of the Bering Sea, mysids may be the most important prey in tertiary feeding grounds for these whales (Kim \& Oliver 1989). Moreover, when their main feeding grounds were absent (Johnson \& Nelson 1984) or inaccessible (Nelson et al. 1974, Hall 1980, Kim \& Oliver 1989), the significance of mysids and invertebrates other than benthic amphipods to the gray whale diet was probably higher.

The occurrence of crab larvae has both life-history and spatio-temporal components (Knudsen 1964). Porcelain crab larvae may comprise more abundant or better-quality prey in nearshore waters at particular times, partially due to the hatching rhythms of Pachycheles spp. and Petrolisthes spp. Hatching increased for both genera of crabs between the end of July and mid-August. At first, the Zoea I larval stage was numerous in plankton samples. Then, 3 wk later, the larger Zoea II larval stage was more numerous. The 2 stages of Pachycheles rudis and P. pubescens last between 24-25 d (Knight 1966) and 34-40 d (Morris et al. 1980) respectively. Small-scale oceanographic events such as current and upwelling may also have served to concentrate these swarms in our study area at specific times.

Greater numbers of gray whales were consistently observed foraging at sites where planktonic prey was present in high densities and biomass. Whales were observed foraging for both mysids and porcelain crab larvae concurrently, indicating that they spread out between the 2 sources of food. This behavior is similar to Fretwell's (1972) ideal free-distribution concept, whereby competitors adjust their distribution in relation to habitat quality so that each individual enjoys the same rate of acquisition of resources (Krebs \& Davies 1987).
The absence of gray whales from benthic prey habitats is usually explained by the availability of other prey such as mysids (Oliver et al. 1984, Kvitek \& Oliver 1986, Guerrero 1989, Duffus 1996). In 1996, no benthic foraging was observed in late August/early September. At this time, planktonic prey were abundant and benthic biomass was generally low. In 1997, whales rapidly switched from planktonic to benthic prey in mid-August, at a time when planktonic prey were less abundant.

While prey density and biomass are linked quite distinctly to whale foraging, the predictability of prey may also be implicated. Distributions of planktonic organisms are less predictable in time and space than those of benthic organisms. It may be beneficial for whales to capitalize on planktonic species first, and forage on these ephemeral organisms when they are encountered. Whales may leave amphipod communities relatively undisturbed until planktonic prey are no longer abundant.

Like other predators, gray whales change their prey preference in response to their own estimate of the densities and profitability of each prey type (Sabelis 1990). Whales observed sporadically bottom feeding in the early summer months may have been exploring and sampling different prey habitats in order to assess the overall quality of food items available.

Size of benthic invertebrates may be an important variable controlling prey-switching behavior in gray whales. It may be beneficial for whales to forage for amphipods later in the summer because these organisms may improve as a food source as the summer progresses. Highsmith \& Coyle $(1990,1992)$ found that the weight and caloric contents of Arctic amphipods increased during the summer, suggesting that energyrich storage compounds such as lipids are accumulated in preparation for winter. We found that amphipods in Clayoquot Sound also increased in size as the summer progressed, but do not know whether their caloric content changed concurrently.

Since amphipod density and biomass were similar in Cow Bay and Ahous Bay in 1997, amphipod size may be the principal reason why gray whales initially did not bottom-feed in Ahous Bay. Amphipod size differed in 4 ways between Cow Bay and Ahous Bay: (1) there were more small amphipods in Ahous Bay; (2) their mean size was smaller than in samples collected near feeding whales and at other locations in Cow Bay; (3) there were fewer large amphipods in Ahous Bay than in Cow Bay where gray whales foraged; (4) large amphipods were smaller in Ahous Bay than in Cow Bay. Prey size and the mechanical limitation imposed by baleen 'mesh' size are important aspects of foraging decision-making by gray whales. 
It is unclear which variables have more influence on prey-switching behavior in gray whales - characteristics of benthic prey populations such as biomass and individual size, or a decline in planktonic prey abundance. In 1997, whales had the opportunity to bottomfeed in Cow Bay throughout the summer, but generally foraged on planktonic instead of benthic prey. When whales switched to bottom-foraging behavior, amphipod density and biomass were not significantly different from those earlier in the summer; amphipod size was the only variable that had changed significantly during the season. These observations indicate that substantial changes in the benthic community were not a likely reason for gray whales switching between planktonic and benthic prey. Rather, the abundance of planktonic prey seemed to drive whales' prey choices.

Sabelis (1990) stated that prey quality is likely to be the ultimate cause of any behavioral change with respect to prey selection. However, differences in the quality of gray whale prey are difficult to measure because other variables are involved, including the energetic costs associated with capturing these prey organisms. Energetic costs are a function of diving depth and costs of specific foraging tactics. Gray whales are consistently characterized as benthic specialists, and in the high latitudes this may be so (Braham 1984). Animals spending the summer in Clayoquot Sound are predominantly pelagic foragers.

The solitary gray whale may have abandoned the ghost shrimp feeding ground in Grice Bay because 4 critical criteria which define foraging success were no longer fulfilled: (1) the length of time the whale had to search for food was too long; (2) it achieved only a low biomass removal rate; (3) ghost shrimp failed to supply the whale's minimum daily energy requirements; (4) the prey species preferred by the whale was no longer abundant.

Whale foraging in Grice Bay has aspects that require more study. This bay was not used by gray whales between 1984 and 1994; then, it was intensively used in 1995 by 5 whales, and sporadically in 1996 and 1997 by a single individual. Grice Bay is not easily reached; whales must traverse several narrow channels and intertidal mudflats to enter it. The small clam Cryptomya californica is abundant in the bay. Should this clam prove a useful energy source for whales, then this would make a significant contribution to the bay's attractiveness. Finally, the bay is shallow and whales do not have to dive for benthic prey, meaning lower energy expenditure; this may partly explain the discrepancy between the observed and the expected pitmaking times.

The gray whales observed in central Clayoquot Sound were highly opportunistic foragers which preyed on concentrations of mysids, porcelain crab larvae, amphipods and ghost shrimp that were present in high density and biomass. Although mysid foraging predominated from June to September, porcelain crab larvae foraging was frequently observed during August. Benthic prey were also utilized by whales; amphipods fell prey to many whales, especially in 1997, whereas ghost shrimp were an important source of food for 1 whale only during the duration of this study.

Prey-switching behavior and prey-habitat selection in gray whales is probably influenced by 2 factors: a decline in the abundance of planktonic prey, and an increase in amphipod size which leads to a high proportion of the amphipod population being $>6 \mathrm{~mm}$ in length. Data indicate that abundance of planktonic prey may be more important than benthic prey size in governing prey-switching behavior in gray whales.

While we can provide no insight into the decisionmaking mechanism of gray whales without more detailed experiments, our study indicates that less predictable (on the basis of availability) prey are preferred over more predictable prey. An ocean forager using very patchy resources (like most baleen whales) would be expected to be highly opportunistic and less selective; however, this small area within their range may provide an opportunity for whales to exhibit more complex foraging strategies. These strategies are an important aspect of the whales' presence in Clayoquot Sound and probably elsewhere in tertiary feeding grounds. With its return to pre-whaling levels, the eastern Pacific gray whale population has once again become a major resource for the recreational whalewatching industry and aboriginal hunters. Scientific management of these activities will require studies on the same scale as the present report to understand, and possibly predict, the spatio-temporal behavior of gray whales.

Acknowledgements. Research was conducted in the traditional territory of the Ahousaht First Nation. Thanks to Chief Earl George and the residents of Ahousaht. C. Malcolm, E. Hines, C. Tombach, S. Meier, H. Patterson, A. Bass, R. Palm, S. Frank, C. Joseph, D. Thomas, D. Frank and ORES volunteers assisted us in the field. J. Forde and W. Atleo provided us with logistical support. L. Hobson, Department of Biology, University of Victoria, provided access to his laboratory, and together with P. Dearden, and P. Lambert, Royal B.C. Museum and several anonymous reviewers, provided helpful comments on the work and this manuscript.

\section{LITERATURE CITED}

Braham HW (1984) Distribution and migration of gray whales in Alaska. In: Jones ML, Swartz S, Leatherwood S (eds) The gray whale (Eschrichtius robustus). Academic Press, Inc., Orlando, FL, p 249-266

Brodie PF (1977) Form, function, and energetics of Cetacea: a discussion. In: Harrison RJ (ed) Functional anatomy of 
marine mammals, Vol. 3. Academic Press, New York, p 45-58

Calambokidis J, Steiger GH, Evenson JR, Cubbage JC, Osborne RW (1991) Gray whales in Puget Sound and the Strait of Juan de Fuca. Proceedings of Puget Sound Research '91, Seattle, Washington, January 4-5. Puget Sound Water Quality Authority, Olympia, Washington, p 414-422

Clarke JT, Moore SE, Ljungblad DK (1989) Observations of gray whale (Eschrichtius robustus) utilization patterns in the northeastern Chukchi Sea, July-October 1982-1987. Can J Zool 67:2646-2654

Duffus DA (1996) The recreational use of grey whales in southern Clayoquot Sound, Canada. Appl Geogr 16: 179-190

Fretwell SD (1972) Populations in a seasonal environment. Princeton University Press, Princeton

Gill RE, Hall JD (1983) Use of nearshore and estuarine areas of the southeastern Bering Sea by gray whales (Eschrichtius robustus). ARCT 36:275-281

Guerrero JA (1989) Feeding behavior of gray whales in relation to patch dynamics of their benthic prey. MSc thesis, San Jose State University, San Jose, CA

Hall JD (1980) Aspects of the natural history of cetaceans of Prince William Sound, Alaska. PhD thesis, University of California, Santa Cruz

Highsmith RC, Coyle KO (1990) High productivity of northern Bering Sea benthic amphipods. Nature 344:862-863

Highsmith RC, Coyle KO (1992) Productivity of arctic amphipods relative to gray whale energy requirements. Mar Ecol Prog Ser 83:141-150

Howell AB, Huey LM (1930) Food of the gray and other whales. J Mammal 11:321-322

Hudnall J (1983) Gray whale feeding behavior along the Vancouver Island coast. Whalewatcher 17:3-5

Johnson KR, Nelson CH (1984) Side-scan sonar assessments of gray whale feeding in the Bering Sea. Science 225: 1150-1152

Kim SL, Oliver JS (1989) Swarming benthic crustaceans in the Bering and Chukchi seas and their relation to geographic patterns in gray whale feeding. Can J Zool 67: 1531-1542

Knight MD (1966) The larval development of Polyonyx quadriungulatus Glassell and Pachycheles rudis Stimpson (Decapoda, Porcellanidae) cultured in the laboratory. Crustaceana 10:75-97

Knudsen JW (1964) Observations of the reproductive cycles and ecology of the common Brachyura and crablike Anomura of Puget Sound, Washington. Pac Sci 18:3-33

Krebs JR, Davies NB (1987) An introduction to behavioral ecology, 2nd edn. Blackwell Scientific Publications, Oxford

Kvitek RG, Oliver JS (1986) Side-scan sonar estimates of the utilization of gray whale feeding grounds along Vancouver Island, Canada. Cont Shelf Res 6:639-654

Mallonée JS (1991) Behavior of gray whales (Eschrichtius robustus) summering off the northern California coast, from Patrick's Point to Crescent City. Can J Zool 69: 681-690

Moore SE, Ljungblad DK (1984) Gray whales in the Beaufort, Chukchi, and Bering Seas: distribution and sound production. In: Jones ML, Swartz S, Leatherwood S (eds) The gray whale (Eschrichtius robustus). Academic Press, Orlando, p 543-559

Editorial responsibility: Otto Kinne (Editor), Oldendorf/Luhe, Germany
Moore SE, Ljungblad DK, van Schoik DR (1986) Annual patterns of gray whale (Eschrichtius robustus) distribution, abundance, and behavior in the northern Bering and eastern Chukchi Seas, July 1980-83. Rep Int Whal Comm Spec Issue 8:231-242

Morris RH, Abbott DP, Haderlie EC (1980) Intertidal invertebrates of California. Stanford University Press, Stanford

Murison LD, Gaskin DE (1989) The distribution of right whales and zooplankton in the Bay of Fundy, Canada. Can J Zool 67:1411-1420

Murison LD, Murie DJ, Morin KR, da Silva Curiel J (1984) Foraging of the gray whale along the west coast of Vancouver Island, British Columbia. In: Jones ML, Swartz S, Leatherwood S (eds) The gray whale (Eschrichtius robustus). Academic Press, Inc, Orlando, p 451-463

Nelson CH, Hopkins DM, Scholl DW (1974) Cenozoic sedimentary and tectonic history of the Bering Sea. In: Wood DW, Kelly CJ (eds) Oceanography of the Bering Sea. University of Alaska, Institute of Marine Science, Fairbanks, p 485-516

Nemoto T (1970) Feeding pattern of baleen whales in the ocean. In: JH Steele (ed) Marine food chains. Oliver \& Boyd, London, p 241-252

Nerini M (1984) A review of gray whale feeding ecology. In: Jones ML, Swartz S, Leatherwood S (eds) The gray whale (Eschrichtius robustus). Academic Press, Orlando, p 423-450

Norris KS, Villa-Ramirez B, Nichols G, Würsig B, Miller K (1983) Lagoon entrance and other aggregations of gray whales (Eschrichtius robustus). In: Payne R (ed) Communication and behavior of whales. AAAS Selected Symposium 76. American Association for the advancement of Science, Washington, p 259-293

Oliver JS, Slattery PN, Silberstein MA, O'Connor EF (1983) A comparison of gray whale, Eschrichtius robustus, feeding in the Bering Sea and Baja California. Fish Bull Calif 81:513-522

Oliver JS, Slattery PN, Silberstein MA, O'Connor EF (1984) Gray whale feeding on dense ampeliscid amphipod communities near Bamfield, British Columbia. Can J Zool 62:41-49

Pike GC (1962) Migration and feeding of the gray whale (Eschrichtius gibbosus). J Fish Res Board Can 19:815-838

Pike GC, MacAskie IB (1969) Marine mammals of British Columbia. Bull Fish Res Board Can 171:1-54

Rice DW, Wolman AA (1971) The life history and ecology of the gray whale (Eschrichtius robustus). Spec Publ Am Soc Mammal 3:142

Sabelis MW (1990) How to analyze prey preference when prey density varies? A new method to discriminate between effects of gut fullness and prey type composition. Oecologia 82:289-298

Sumich JL (1984) Gray whales along the Oregon coast in summer, 1977-1980. Murrelet 65:33-40

Walker LW (1949) Nursery of the gray whales. Nat Hist 58: 248-256

Weitkamp LA, Wissmar RC, Simenstad CA, Fresh KL, Odell JG (1992) Gray whale foraging on ghost shrimp (Callianassa californiensis) in littoral sand flats of Puget Sound, USA. Can J Zool 70:2275-2280

Zimushko VV, Lenskaya SA (1970) Feeding of the gray whale (Eschrichtius robustus Erx.) at foraging grounds. Ekologiya (Sverdl) 1:205-212

Submitted: September 20, 2000; Accepted: February 15, 2001 Proofs received from author(s): November 1, 2001 